Piwulang 8(1)(2020)
Teaching
http://journal.unnes.ac.id/sju/index.php/piwulang

\title{
PENGEMBANGAN MEDIA FLASH PLAYER DALAM PEMBELAJARAN LEGENDA UNTUK SISWA KELAS VIII SMP 2 DAWE KUDUS
}

\author{
Azmatun Nafi' ah' ${ }^{1}$, Endang Kurniati ${ }^{2}$ \\ 1,2Jurusan Bahasa Jawa, Fakultas Bahasa dan Seni, Universitas Negeri Semarang, Indonesia \\ Corresponding Author azmatunnafiah00@gmail.com ${ }^{1}$
}

\begin{abstract}
Abstrak
Pembelajaran legenda merupakan pembelajaran yang memberikan pengetahuan kepada siswa tentang suatu kejadian yang dianggap benar-benar terjadi pada zaman dahulu. Cerita legenda mengandung nilai-nilai teladan yang baik seperti nilai religius, sosial, dan budaya yang dapat dijadikan contoh untuk membentuk pribadi siswa menjadi lebih baik. Oleh karena itu, pembelajaran legenda penting diajarkan kepada siswa di sekolah, tetapi pembelajaran legenda di SMP 2 Dawe Kudus kurang diminati siswa. Permasalahan tersebut dikarenakan kegiatan belajar mengajar selama ini berjalan secara konvensional dan tidak variatif serta kurang memanfaatkan sarana LCD yang telah terpasang di setiap kelas. Selain itu, pembelajaran legenda di SMP 2 Dawe Kudus menggunakan materi Legenda Bulusan dari LKS berupa teks tulis yang kurang konstektual. Oleh karena itu, diperlukan inovasi untuk mengembangkan media pembelajaran yang lebih kreatif seperti media flash player yang berupa film animasi agar dapat meningkatkan minat belajar siswa. Pendekatan yang digunakan dalam penelitian ini adalah Research and Development $(R \& D)$ yang dilakukan dengan lima tahapan, meliputi analisis potensi dan masalah, pengumpulan data, desain produk, validasi desain, dan uji coba produk. Subjek penelitian ini adalah guru pengampu mata pelajaran bahasa Jawa, siswa kelas VIII SMP 2 Dawe Kudus, juru kunci cerita legenda, pakar ahli materi, pakar ahli media, dan guru sebagai pengguna media. Teknik pengumpulan data penelitian menggunakan angket, wawancara, tes, dan observasi. Data yang terkumpul dianalisis secara deskriptif kuantitatif. Hasil penelitian menunjukkan adanya perbedaan hasil belajar siswa. Nilai rata-rata hasil belajar kelas eksperimen lebih tinggi dibandingkan dengan siswa kelas kontrol.
\end{abstract}

Kata Kunci: legenda; media pembelajaran; pengembangan

\begin{abstract}
Learning legend is a learning that provides knowledge to students about an event that is considered really happened in ancient times. Legend stories contain good exemplary values such as religious, social, and cultural values that can serve as examples to better shape student personalities. Therefore, important legend learning is taught to students at school, but the learning of the legend at SMP 2 Dawe Kudus is of less interest to the students. The problem is because the teaching and learning activities during this run in conventional and not varied and less use of $L C D$ facilities that have been installed in each class. In addition, the learning of the legend in SMP 2 Dawe Kudus using the material Legend Bulusan from LKS in the form of text that is less konstektual. Therefore, innovation is required to develop a more creative learning media such as flash media in the form of animated films in order to increase student interest in learning. The approach used in this research was Research and Development $(R \& D)$ which conducted with five stages, including potential and problem analysis, data collection, product design, design validation, and product testing. The subjects of this research were teacher of Javanese subject, students of grade VIII SMP 2 Dawe Kudus, interprete of legend story, material expert, media expert, and media user. Data collection used in this research is questionnaires, interview guides, test, and obsevation. The data was analyzed in qualitative-descriptive. The results showed of students the experimental class that performed higher learning outcomes than the control class.

Keywords: legend; learning media; development
\end{abstract}

(C) 2020 Universitas Negeri Semarang

p-ISSN 2252-6307

e-ISSN 2714-867X 
Azmatun Nafi'ah, Endang Kurniati/ Piwulang 8 (1) (2020)

\section{PENDAHULUAN}

Tujuan dari pembelajaran Bahasa Jawa sesuai Kurikulum 2013 mata pelajaran Bahasa Jawa adalah meningkatkan kemampuan peserta didik untuk berkomunikasi dalam bahasa Jawa dengan baik dan benar. Sesuai kurikulum 2013 mata pelajaran bahasa Jawa Provinsi Jawa Tengah kelas VIII SMP pada semester genap terdapat Kompetensi Dasar (KD) memahami teks legenda yang mencakup kompetensi membaca dan mendengar. Pembelajaran legenda mengandung beberapa nilai seperti nilai religious, sosial, dan budaya yang dapat dijadikan contoh teladan untuk membentuk pribadi siswa menjadi lebih baik. Oleh karena itu, pembelajaran legenda penting diajarkan kepada siswa di sekolah.

Walaupun kegiatan pembelajaran legenda sering diajarkan di sekolah, banyak siswa yang masih kesulitan dalam pembelajaran legenda. Keadaan tersebut dapat terjadi diperkirakan karena adanya komponen yang kurang dalam pembelajarannya. Berdasarkan hasil observasi di sekolah SMP 2 Dawe Kudus dalam kegiatan pembelajaran memahami teks legenda kelas VIII pada semester genap masih mengalami beberapa permasalahan yang menyebabkan pembelajaran kurang berjalan efektif. Sebagian besar siswa belum mampu menceritakan kembali isi legenda yang disebabkan oleh beberapa faktor dari cara mengajar guru yang masih konvesional dan penggunaan media yang kurang menarik perhatian siswa dalam belajar. Guru bergantung pada LKS dan isi materi LKS pada pembelajaran legenda adalah Legenda Bulusan yang kurang konstektual. Relevan dengan keadaan tersebut, perlu diadakan inovasi pengembangan media pembelajaran legenda yang kreatif supaya siswa lebih berminat mengikuti kegiatan pembelajaran legenda. Sukiman (2012:29) menyatakan media pembelajaran adalah segala sesuatu yang dapat digunakan untuk menyalurkan pesan dari pengirim kepada penerima sehingga merangsang pikiran, perasaan, perhatian dan minat serta kemauan peserta didik sedemikian rupa sehingga proses belajar terjadi dalam rangka mencapai tujuan pembelajaran secara efektif. konsep media pembelajaran yang dapat dipakai adalah alat penyalur pesan yang disusun dan digunakan guru untuk memahamkan peserta didiknya supaya mencapai tujuan pembelajaran yang efektif dalam kegiatan belajar mengajar.

Bentuk media pembelajaran memahami teks legenda yang akan dikembangkan dalam penelitian ini sesuai dengan permasalahan yang ada di SMP 2 Dawe Kudus yaitu memberikan alternatif dengan membuat film animasi Legenda Bulusan melalui program flash player. Flash Player merupakan suatu program untuk mendesain dan membuat sebuah media dalam bentuk video atau film, audio dan grafik untuk keperluan iklan atau promo, presentasi, dan sebagainya supaya lebih efektif dan menarik minat audien (Zarkoni, 2014). Sebuah jurnal yang ditulis oleh Donald (2011) juga mengatakan media Flash Player mempunyai solusi yaitu menyediakan video, interaktivitas dan praktek simulasi untuk melibatkan peserta didik dalam konten, meningkatkan retensi dan transfer ilmu. Terlebih jika dibuatkan media film animasi yang dekat dengan kesenangan hati siswa sehari-hari, 
Azmatun Nafi'ah, Endang Kurniati/ Piwulang 8 (1) (2020)

maka akan menciptakan ketertarikan siswa dalam mengikuti pembelajaran.

\section{METODE PENELITIAN}

Penelitian ini menggunakan desain penelitian dan pengembangan atau Research and Development (R\&D), yaitu metode penelitian yang digunakan untuk menghasilkan produk tertentu dan menguji keefektifan produk tersebut (Sugiyono, 2010). Menurut Sugiyono (2010:409) langkah-langkah penelitian dan pengembangan terdapat sepuluh langkah meliputi: (1) potensi dan masalah, (2) pengumpulan data, (3) desain produk, (4) validasi desain, (5) uji coba produk, (6) revisi produk, (7) uji coba pemakaian, (8) revisi desain, (9) revisi produk, (10) produksi masal. Tujuan penelitian ini adalah menghasilkan media film animasi legenda yang lebih kreatif dan menyenangkan untuk digunakan dalam proses pembelajaran memahami isi teks legenda. Oleh karena itu, dari sepuluh langkah yang disebutkan oleh Sugiyono, hanya 5 langkah saja yang akan digunakan yaitu analisis potensi dan masalah, analisis kebutuhan guru dan siswa, desain produk, validasi desain, dan uji coba produk.

Subjek pada penelitian ini meliputi 36 siswa kelas VIII F, satu guru pengampu mata pelajaran bahasa Jawa di SMP 2 Dawe Kudus, satu pakar materi, dan 1 pakar media. Instrumen yang digunakan dalam penelitian ini meliputi pedoman wawancara untuk mencari informasi mengenai media dan materi pembelajaran memahami teks legenda, lembar angket kebutuhan guru dan siswa yang digunakan sebagai acuan penyusunan media, lembar angket validasi desain untuk menilai kelayakan media, dan lembar tes soal untuk uji coba media yang telah disusun.

Teknik analisis data yang digunakan dalam penelitian ini menggunakan teknik deskriptif kuantitatif. Data uji coba akan dianalisis dengan mencari nilai rata-rata siswa satu kelas setelah menggunakan media film animasi flash player.

\section{HASIL DAN PEMBAHASAN}

Pengembangan media pembelajaran legenda yang telah dilakukan sesuai tahap-tahap prosedur pengembangan yang telah ditentukan. Tahap-tahap penelitian dijalankan secara runtut, yaitu dimulai dari analisis potensi dan masalah, analisis kebutuhan guru dan siswa, desain produk, validasi desain, dan uji coba produk.

\section{Analisis Potensi dan Masalah}

Siswa kelas VIII SMP 2 Dawe Kudus mampu menggunakan Bahasa Jawa ragam ngoko sesuai dengan dialek Kudus untuk berkomunikasi dengan teman sebayanya. Bahasa Jawa ragam ngoko dialek Kudus merupakan Bahasa dominan yang digunakan dalam percakapan siswa seharihari. Namun kemampuan siswa dalam berbahasa Jawa kurang diimbangi dengan bimbingan yang mengarahkan siswa untuk mengembangkan kemampuan berbahasa Jawa ragam krama. Banyak siswa yang mengalami kesulitan dalam berbicara Bahasa Jawa ragam krama. 
Azmatun Nafi'ah, Endang Kurniati/ Piwulang 8 (1) (2020)

Adapun masalah lain yang ditemukan yaitu kurangnya pemanfaatan sarana LCD yang telah disediakan untuk pembelajaran di dalam kelas. Sementara itu, terdapat hambatan dalam proses belajar dan mengajar yang berasal dari guru pengampu mata pelajaran Bahasa Jawa di kelas VIII SMP 2 Dawe Kudus. Latar belakang pendidikan guru Bahasa Jawa SMP 2 Dawe Kudus sudah sesuai dengan disiplin ilmunya. Namun, teknik mengajar yang disajikan oleh guru Bahasa Jawa SMP 2 Dawe kurang menarik. Teknik mengajar yang digunakan oleh guru Bahasa Jawa kelas VIII SMP 2 Dawe Kudus masih sering berjalan secara konvensional dan tidak variatif. Guru cenderung hanya memanfaatkan penggunaan LKS dan buku paket. Keadaan tersebut membuat siswa mudah merasa bosan sehingga hasil belajar siswa banyak yang tidak tercapai.

\section{Analisis Kebutuhan Guru dan Siswa}

Kebutuhan guru terhadap media pembelajaran legenda dijelaskan bahwa guru pengampu mata pelajaran bahasa Jawa di SMP 2 Dawe Kudus membutuhkan media audiovisual film animasi untuk menarik perhatian siswa sehingga siswa akan lebih jelas dalam menerima materi legenda. Materi legenda yang diharapkan guru adalah materi legenda yang syarat dengan nilai religius, sosial, dan budaya yang dapat membentuk sikap siswa menuju sikap yang lebih bermoral, santun, dan mengenal serta menjaga budaya yang berasal dari daerahnya. Selain itu, ragam bahasa yang digunakan dalam media pembelajaran legenda juga perlu diperhatikan. Siswa di SMP 2
Dawe Kudus masih dalam tahap belajar bahasa Jawa ragam krama sehingga sebagian siswa masih ada yang kesulitan memahami bahasa Jawa ragam krama. Oleh karena itu, mengingat bahwa kurikulum 2013 Provinsi Jateng untuk siswa SMP pada mata pelajaran bahasa Jawa harus sudah bisa berbahasa Jawa ragam krama dan untuk memudahkan siswa kelas VIII SMP 2 Dawe Kudus dalam memahami materi yang akan diberikan, penggunaan bahasa pada materi legenda lebih baik menggunakan bahasa ragam ngoko dan ragam krama yang disesuaikan berdasarkan konteksnya. Selain penggunaan bahasa, durasi media yang akan dirancang juga perlu diperhatikan. Guru pengampu bahasa Jawa di SMP 2 Dawe Kudus menyetujui media yang berdurasi kurang lebih 10 menit, mengingat waktu pembelajaran berlangsung selama $2 \times 40$ menit.

Berdasarkan data yang diperoleh dari angket, peneliti menemukan dua aspek terkait kebutuhan siswa kelas VIII SMP 2 Dawe Kudus terhadap media pembelajaran teks legenda. Aspek yang pertama dapat dijelaskan bahwa siswa kelas VIII SMP 2 Dawe Kudus membutuhkan media pembelajaran legenda yang lebih menarik. Hampir seluruh siswa menyatakan ketertarikan mereka terhadap penggunaan media pembelajaran seperti media film kartun dengan kualitas gambar yang cerah. Aspek yang ke-dua yaitu mengenai materi yang digunakan dalam media pembelajaran teks legenda. Terkait kebutuhan siswa pada aspek tersebut, siswa menyatakan bahwa mereka lebih suka mempelajari materi legenda yang berada di daerahnya sendiri karena siswa 
Azmatun Nafi'ah, Endang Kurniati/ Piwulang 8 (1) (2020)

sebelumnya telah mendengar mengenai ceritacerita legenda di daerahnya. Selain itu, siswa juga menyatakan bahwa dengan menghadirkan materi legenda dari daerahnya akan mempermudah siswa dalam mempelajari dan memahami legenda berbahasa Jawa khususnya ragam krama. Oleh karena itu, siswa setuju jika materi yang akan digunakan adalah cerita Legenda Bulusan.

\section{Desain Produk}

Dasar pengembangan media pembelajaran legenda tidak hanya didasarkan pada analisis kebutuhan guru dan siswa di SMP 2 Dawe Kudus, namun juga didasarkan pada kurikulum yang diterapkan oleh pihak sekolah sebagai acuan pembelajaran Bahasa Jawa, yaitu kurikulum 2013. Pemilihan cerita legenda yang digunakan dalam media pembelajaran didasarkan pada kompetensi inti pada kurikulum 2013. Terdapat 2 sikap yang harus dicapai siswa dalam pembelajarannya, yaitu sikap spiritual dan sosial. Sesuai dengan kompetensi yang harus dicapai tersebut, maka teks legenda yang digunakan dalam pengembangan media pembelajaran adalah teks legenda keagamaan.

Pembuatan media pembelajaran legenda melalui beberapa proses meliputi menentukan cerita, membuat story board, menggambar, menganimasi, mengisi suara, dan membuat desain sampul media. Produk media pembelajaran legenda berupa film animasi flash player yang dikemas dalam bentuk piringan DVD. Cerita Legenda Bulusan yang dikemas dalam film animasi tersebut mengisahkan tentang asal mula tradisi keagamaan masyarakat Islam di Kabupaten Kudus, Jawa Tengah.

Adapun cara penggunaan produk media pembelajaran legenda sangat mudah. Pertama yaitu memasukkan piringan DVD kedalam laptop yang telah disambungkan ke proyektor atau LCD. Kemudian, pengguna dapat memutar film tersebut dengan aplikasi media player.

\section{Validasi Materi}

Pada uji validasi materi terdapat tiga aspek meliputi kelayakan materi pembelajaran, kebahasaan, dan keselarasan isi materi. Aspek kelayakan materi pembelajaran sudah baik dan sesuai, tetapi pada aspek kebahasaan dan keselarasan isi materi masih terdapat permasalahan yang perlu diperbaiki. Permasalahan pada aspek kebahasaan meliputi diksi dan kesinambungan kalimat, sedangkan aspek keselaran isi meliputi uraian materi dan narasi pada setiap adegan yang terlalu panjang. Hasil uji validasi materi setelah perbaikan mendapatkan rata-rata skor 4 dari rentang skor 1 sampai dengan 5, artinya materi yang akan digunakan dalam media pembelajaran legenda sudah baik dan siap untuk diproduksi.

\section{Validasi Desain Media}

Terdapat dua aspek penilaian dalam angket uji validasi media meliputi aspek kelayakan sampul media dan spesifikasi isi media. Kekurangan pada aspek kelayakan sampul media, yaitu jenis huruf penulisan judul yang susah dibaca dan 
Azmatun Nafi'ah, Endang Kurniati/ Piwulang 8 (1) (2020)

warna huruf yang tidak menarik, sementara komposisi warna pada sampul media tidak sinkron dengan objek gambar. Kekurangan pada aspek spesifikasi isi media yaitu mengenai volume suara backsound yang terlalu keras, sedangkan volume narasi terlalu lirih. Oleh karena itu, ahli media memberikan saran agar volume backsound dilirihkan atau volume narasi dikeraskan. Hasil uji validasi desain media setelah perbaikan mendapatkan rata-rata skor 4,4 dari rentang skor 1 sampai dengan 5 . Artinya, media yang telah disusun sudah baik dan siap untuk diujicobakan.

\section{Validasi Pengguna Media}

Terdapat dua aspek penilaian pada angket uji validasi pengguna media, yaitu aspek kesesuaian antara konsep dan kompetensi serta kualitas tampilan. Menurut guru Bahasa Jawa SMP 2 Dawe Kudus tidak ada kekurangan pada media yang telah disusun, secara keseluruhan sudah baik dan sudah memenuhi kebutuhan pengguna media. Hasil uji validasi desain media mendapatkan rata- rata skor 4,7 dari rentang skor 1 sampai dengan 5. Artinya, media yang telah disusun sudah baik dan siap untuk diujicobakan kepada siswa kelas VIII di SMP 2 Dawe Kudus.

\section{Uji Coba Produk}

Tahap uji coba dilakukan sebanyak satu kali terhadap kelompok eksperimen dan kontrol. Pada proses uji coba, kelas kontrol menerima pembelajaran seperti biasanya yaitu tidak menggunakan media flash player film animasi, sedangkan uji coba kelas eksperimen menggunakan media flash player film animasi. Setelah memahami teks legenda dalam pembelajaran, baik siswa kelas eksperimen maupun kontrol diberi lembar soal dan mengerjakannya selama 20 menit.

Hasil uji coba diperoleh dari tes pilihan ganda dan keterampilan menulis yang telah dikategorikan dengan menggunakan angka pada skala 0-100 dan deskripsi sesuai dengan Panduan Penilaian Kurikulum 2013 untuk Sekolah Menengah Pertama sebagai berikut:

Tabel 4.3 Rentang Nilai Uji Coba Media Kelas Kontrol dan Eksperimen

\begin{tabular}{cccc} 
Skala & Deskripsi & \multicolumn{2}{c}{ Frekuensi } \\
\cline { 3 - 4 } Nilai & & $\begin{array}{c}\text { Kelas } \\
\text { Kontrol } \\
\text { dari 36 } \\
\text { Siswa }\end{array}$ & $\begin{array}{c}\text { Kelas } \\
\text { Eksperi } \\
\text { men dari } \\
\text { 32 Siswa }\end{array}$ \\
& & & \\
\hline $86-$ & Sangat & 0 & 19 \\
100 & Baik & & 13 \\
$71-85$ & Baik & 21 & 0 \\
$56-70$ & Cukup & 15 & 0 \\
\hline$\leq 55$ & Kurang & 0 &
\end{tabular}

Berdasarkan tabel tersebut, diketahui bahwa terdapat perbedaan perolehan rata-rata nilai hasil belajar siswa kelas kontrol dengan kelas eksperimen. Pada kelas kontrol terdapat 15 siswa yang mendapat nilai dengan skala 5670 yang masuk pada kategori deskripsi cukup. Pada kelas eksperimen terdapat 13 siswa yang mendapat nilai dengan skala 71-85 dengan kategori deskripsi baik dan 19 siswa mendapat nilai dengan skala 86-100 dengan kategori deskripsi sangat baik. Nilai tertinggi pada kelas kontrol adalah 85 , sedangkan nilai tertinggi 
Azmatun Nafi'ah, Endang Kurniati/ Piwulang 8 (1) (2020)

pada kelas eksperimen adalah 94. Rata-rata nilai kelas antara kelas kontrol dengan kelas eksperimen menunjukkan perbedaan. Nilai ratarata kelas kontrol adalah 73,4 yang masuk kategori baik, sedangkan kelas eksperimen adalah 86 yang masuk kategori sangat baik. Oleh karena itu, dapat disimpulkan bahwa hasil belajar siswa kelas eksperimen lebih baik dari pada kelas kontrol.

\section{SIMPULAN}

Berdasarkan hasil penelitian dapat disimpulkan bahwa guru dan siswa kelas VIII SMP 2 Dawe Kudus membutuhkan media pembelajaran legenda yang lebih kreatif dan inovatif. Prototipe media pembelajaran legenda berupa film animasi dua dimensi yang dikemas dalam piringan DVD. Materi media pembelajaran legenda yang digunakan adalah Legenda Bulusan yang berasal dari Kabupaten Kudus. Adapun bahasa yang digunakan dalam media pembelajaran legenda adalah bahasa Jawa ragam ngoko dan krama yang disesuaikan berdasarkan koteksnya. Uji validasi media yang dihasilkan sudah valid. Ratarata skor uji validasi mendapatkan skor 4,3 yang mengarah pada kategori sangat baik dari skor maksimal 5. Nilai rata-rata kelas eksperimen adalah 86 yang masuk kategori sangat baik, sedangkan kelas kontrol adalah 73,4 yang masuk kategori baik. Oleh karena itu, dapat disimpulkan bahwa media pembelajaran legenda berupa film animasi dapat menjadi alternatif bagi guru untuk memudahkan siswa dalam memahami cerita legenda dengan jelas. Hal ini ditunjukkan dengan hasil belajar siswa kelas eksperimen yang lebih baik dibandingkan dengan siswa kelas kontrol.

\section{DAFTAR PUSTAKA}

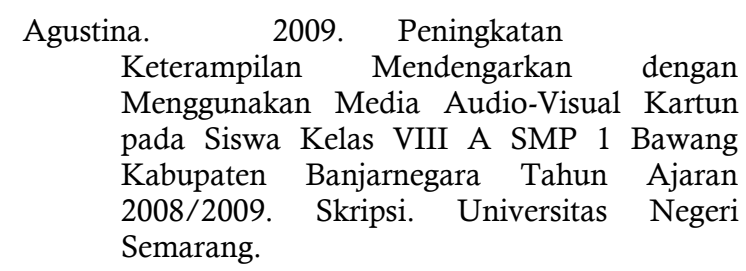

Arsyad, Azhar. 2009. Media Pembelajaran. Jakarta: PT. Raja Grafindo Persada.

Bangerter, Andrian. 2004. "The Mozart Effect: Tracking The Evolution Of a Scientific Legend". British Journal of Social Psychology. Nomor 43:607. USA: Stanford University.

Basyiruddin, Usman dan Asnawir. 2002. Media Pembelajaran. Jakarta: PT. Intermasa.

Daryanto. 2011. Media Pembelajaran. Bandung: PT. Sarana Tutorial Nurani Sejahtera.

Donald, Jo E. 2011. "Mobile Interactive Training: Tablets, Readers, and Phones". Interservice, Simulation, and Education Conference. Nomor 11038:8. Pensacola: General Dynamics Information Technology.

Fuady, Cut Azhar. 2015. "Pengembangan Media Animasi Flash Player pada Materi Laju Reaksi di SMK N 1 Banda Aceh". Jurnal Pendidikan dan Teknologi Informasi. Volume 1 Nomor 1:35. Aceh: Universitas Islam Negeri ArRaniry.

Heni. 2009. Peningkatan Keterampilan Mendengarkan Menggunakan Media AudioVisual Animasi pada Siswa Kelas VII D SMP 1 Margasari Kabupaten Tegal. Skripsi. Universitas Negeri Semarang.

Kustandi, Cecep. 2011. Media Pembelajaran. Bogor: Ghalia Indonesia.

Rohani, Ahmad. 2014. Media Instruksional Edukatif. Jakarta: Rineka Cipta.

Sadiman, Arief S. dkk. 2011. Media Pendidikan. Jakarta: PT. Raja Grafindo Persada. 
Azmatun Nafi'ah, Endang Kurniati/ Piwulang 8 (1) (2020)

Sambodo, Titis. 2013. Pengembangan Media Pembelajaran Integratif CeritaRakyat dalam Pembelajaran Bahasa Jawa SD di Kabupaten Semarang Aspek Mendengarkan dan Berbicara. Skripsi. Universitas Negeri Semarang.

Setyoningsih, Irawati. 2009. "Legenda Keong Mas sebagai Sumber Ide dalam Perancangan Motif Tekstil untuk Pakaian Muslimah". Motif Tekstil. Nomor 981:15. Surakarta: Universitas Sebelas Maret.

Sugiyono. 2010. Metode Penelitian Pendidikan. Bandung: CV Alfabeta.

Sutopo, Hadi. 2011. "Selection Algorithm Visualization Using Flash". The Interntional Jurnal of Multimedia and Its Applications. Volume 3. Nomor 1:4. Jakarta: Universitas Persada Indonesia.

Syamsul. 2010. Penerapan Media Film Animasi Sebagai Upaya Peningkatan Keterampilan Menceritakan Kembali Cerita Berbahasa Jawa Siswa Kelas VII B di SMP N 1 Subah. Skripsi. Universitas Negeri Semarang.

Zarkoni. 2014. "The Use of Macromedia Flash Player to Increase Vocabulary Mastery in The Seventh Grade of MTs SA PANCASILA SALATIGA in The

Academic Year of 2013/2014". Journal of Education and Information Technology. Nomor 1:10. Salatiga: State Institute for Islamic Studie. 